\title{
A NOTE ON THE PRESENCE OF A MUSCULUS CLEIDO- ATLANTICUS IN THE DOMESTIC CAT (FELIS DOMESTICA)
}

\author{
RANDOLPH WEST \\ Laboratory of Comparative Anatomy, Princeton University \\ ONE FIGURE
}

So far as is known to the writer the musculus cleido-atlanticus (Gruber) ${ }^{\prime}$ has never been described as occurring in the cat, nor in any other mammal in which the clavicle is rudimentary. In order to avoid confusion, the nomenclature used by Reighard and Jennings ${ }^{2}$ will be followed throughout this paper, and, in addition, the term cleido-atlanticus will be used to designate a muscle, hitherto not described in the cat, arising from the atlas and inserting into the clavicle.

Both the $\mathrm{m}$. levator scapulae ventralis (levator claviculae) which arises from the atlas and inserts into the metacromion, and the m. cleido-atlanticus have been described as anomalies in man by Testut, ${ }^{1}$ under the common name of the $\mathrm{m}$. cleidoomo-transversaire and by Le Double, ${ }^{3}$ under the common name of the $\mathrm{m}$. omo-trachellien. The $\mathrm{m}$. cleido-atlanticus is found alone in the anthropoid apes, as well as in Nycticibus tardigradus and Cynocephalus anubis, while it is present in connection with the $\mathrm{m}$. levator scapulae ventralis in the orang. Always one and occasionally both of these muscles occur regularly in all vertebrates except the fishes, birds and man. In some vertebrates these muscles may have origins from the basi-occipital and from the posterior cervical vertebrae in addition to the atlantal origin. For a fuller account of the comparative anatomy

\footnotetext{
${ }^{1}$ Testut, Les anomalies musculaires chez l'homme. 1884, p. 97.

${ }^{2}$ Reighard and Jennings, Anatomy of the cat. 1901.

${ }^{3}$ Le Double, Variations du système musculaire de l'homme. 1897. T. 1, p.
} 235. 
of the $\mathrm{m}$. cleido-atlanticus the reader is referred to the articles of Testut and Le Double cited above.

The m. cleito-atlanticus (4, fig. 1) was found in one adult female cat and was present on both sides of the body. Out of some four hundred cats dissected in the laboratiory this is the

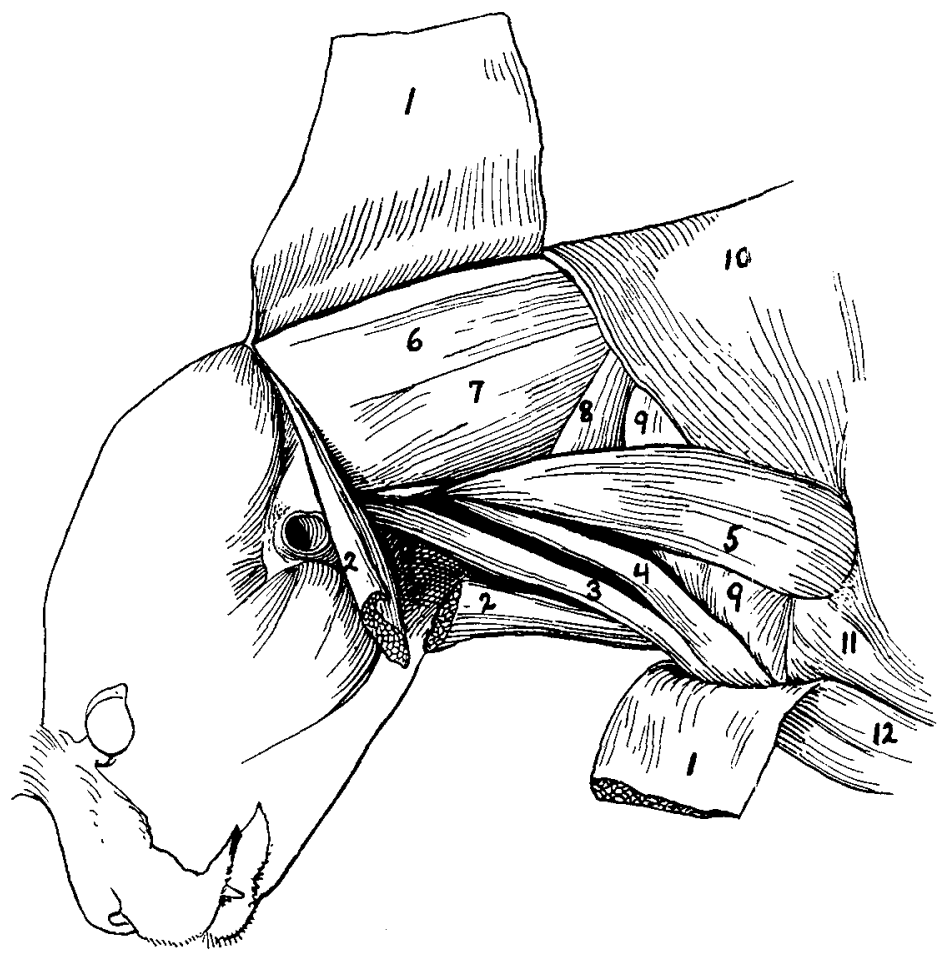

Fig. 1 1, M. clavotrapezius; 2, M. sternomastoideus; 3, M cleidomastoideus; 4, M. cleido-atlanticus; 5, M. levator scapulae ventralis (levator claviculae); 6 , M. occipitoscapularis (levator scapulae dorsalis); 7 , M. splenius; 8 . M. levator scapulae; 9 , M. supraspinatus; 10 , M. acromiotrapezius; i' 1 , M. acromiodeltoideus; 12 , M. clavobrachialis.

first one in which this muscle has been observed. It arises in common with the $\mathrm{m}$. levator scapulae ventralis (5) from the posterior portion of the transverse process of the atlas. After about $0.5 \mathrm{~cm}$. the two muscles separate, and the $\mathrm{m}$. levator scapulae ventralis inserts into the metacromion. The $\mathrm{m}$. cleido- 
atlanticus inserts into the lateral third of the clavicle and into the raphe which lies lateral to the clavicle, between the m. clavotrapezius (1) and the m. clavobrachialis (12). About $1.75 \mathrm{~cm}$. before its insertion it is joined on its medial border by the $\mathrm{m}$. cleidomastoideus (3), which inserts into the medial two-thirds of the clavicle. The $\mathrm{m}$. cleido-atlanticus is an elongated muscle, somewhat flattened at the clavicular end. It is about $6 \mathrm{~cm}$. in length, $0.25 \mathrm{~cm}$. broad at the atlas, $1 \mathrm{~cm}$. broad at the clavicle and $0.5 \mathrm{~cm}$. thick in the cat here described. The innervation is from the ventral ramus of the third cervical nerve which also supplies the $\mathrm{m}$. levator scapulae ventralis, the $\mathrm{m}$. cleidomastoideus, the m. sternomastoideus (2) and several other muscles of this region. 


\section{ANTI-VIVISECTION MORALS}

It makes no difference to an anti-vivisectionist how hard a blow she receives from the facts. She comes up smiling just the same. Dr. Keen, the famous Philadelphia surgeon, exposed recently a number of the latest lies, and Mrs. Fenderson, vicepresident of the American Anti-Vivisection Society, came back with the most cheerful and unmoved assertion of her own opinion and interpretation against overwhelming evidence. Then comes along Dr. Crile. Mrs. Henderson had quoted Dr. Crile's book on "Surgical Shock," saying that it "repeatedly describes experiments followed by the words 'no anesthesia." " Dr. Crile has studied his own book faithfully, and cannot discover any such words. We have not yet noticed Mrs. Henderson's answer to Dr. Crile, but feel sure that it will be just as cheerful as her answer to Dr. Keen. Harper's Weekly, January 24, 1914.

\section{SCIENCE AND MERCY}

The Anti-vivisectionists have been putting out a circular in Philadelphia, with the statement that Dr. George W. Crile made experiments on one hundred and forty-eight dogs "in an endeavor to learn the extent of the agony that can be inflicted on a living animal." Do the kind-hearted women who are backing this.movement believe that Dr. Crile did anything of the sort? When they leave out all mention of anaesthesia, do they do it by accident? Surgeons until recently thought that when a patient was unconscious they could tear loose adhesions and manipulate tissues roughly without doing mischief. Crile's experiments were to determine whether this view was correct. $\mathrm{He}$ found that it was not; that serious injury could be caused by shock even when there was no consciousness. Realizing the difference between psychic shock, which is prevented by anaesthesia, and traumatic shock, which is not prevented by anaesthesia, is an important step ahead, which has already resulted in a lower death rate and a shorter time for recovery. Crile, like other men of science who are called monsters of cruelty by these kind but ignorant sentimentalists, is the apostle of gentleness. Harper's Weekly, January 31, 1914. 